\title{
Pengaruh Penjajaran Strategik di Antara Strategi Sistem Maklumat dan Strategi Pengurusan Organisasi Terhadap Kejayaan Sistem Maklumat
}

\section{Impacts of Strategic Alignment between System's Strategy and Organization's Strategy on Information System's Success}

\author{
Razana Baharudin ${ }^{\mathrm{a}}$, Mohamed Ibrahim ${ }^{\mathrm{b}}$ \\ ${ }^{a}$ Universiti Pendidikan Sultan Idris, Malaysia, razana@fskik.upsi.edu.my \\ ${ }^{b}$ Universiti Pendidikan Sultan Idris, Malaysia, mohamad@fskik.upsi.edu.my
}

\begin{abstract}
Abstrak
Elemen pengurusan seperti strategi sistem maklumat dan strategi pengurusan organisasi mempengaruhi corak penggunaan sesuatu sistem maklumat. Di samping itu penjajaran strategik di antara kedua-dua elemen tersebut juga mempengaruhi corak penggunaan sesuatu sistem maklumat di sesebuah organisasi. Kajian ini melihat kepada pengaruh elemen-elemen pengurusan tersebut terhadap kejayaan sistem maklumat. Sampel kajian terdiri daripada 375 orang guru yang bertugas di sekolah menengah di daerah Hulu Perak, daerah Kuala Kangsar, daerah Muallim, dan daerah Kinta. Data dikumpul melalui borang soal selidik, dan dianalisa mengguna statistik diskriptif, korelasi, dan analisis regresi berganda langkah demi langkah. Dapatan menunjukkan strategi sistem maklumat, strategi pengurusan organisasi serta penjajaran strategik di antara strategi sistem maklumat dengan strategi pengurusan organisasi mempunyai hubungan yang kuat dengan kejayaan sistem maklumat, serta merupakan peramal penting yang mempengaruhi kejayaan sistem maklumat. Oleh itu, bagi memastikan kejayaan sistem maklumat yang digunakan, organisasi perlulah memberi tumpuan kepada perancangan berkaitan dengan strategi sistem maklumat dan strategi pengurusan organisasi serta penjajaran strategik di antara strategi sistem maklumat dan strategi pengurusan organisasi. Penemuan kajian ini dapat dimanfaatkan oleh para penyelidik dalam bidang ini dan juga kepada para pelaksana sistem maklumat di organisasi. Penemuan ini dapat dijadikan panduan kepada pihak-pihak yang terlibat dalam merancang dan mengatur strategi agar sistem maklumat dapat diguna secara efektif dan efisyen serta dapat membantu meningkatkan pencapaian organisasi.
\end{abstract}

Kata kunci: penjajaran strategik, strategi sistem maklumat, strategi pengurusan organisasi, kejayaan sistem maklumat

\begin{abstract}
Organization features such as system strategies, organization strategies and the alignment/fit between these strategies influence on how organizations use their information systems. This study examines impacts of strategic alignment between system's strategy and organization's strategy on information system's success. A quantitative study was constructed using surveys involving 375 educators at several schools in Hulu Perak, Kuala Kangsar, Muallim, and Kinta District. This study applied descriptive statistic, correlation, and multiple regression stepwise analysis to analyse the data. The findings show that information system strategies, organization management strategies, and the strategic alignment between information system strategies and organization management strategies, are positively correlated with information system's success. Thus, this study suggested that information system strategies, organization management strategies, and the strategic alignment between information system strategies and organization management strategies act as important predictors for system's success. The findings serve as a guideline for practitioners as it suggests the new ways and means by which organizations can improve the information system implementation process.
\end{abstract}

Keywords: strategic alignment, information system strategies, organization management strategies, system's success 


\section{PENGENALAN}

Fungsi sistem maklumat telah berubah selaras dengan perkembangan teknologi masa kini. Daripada fungsi sistem maklumat hanya sebagai alat yang membantu pengurusan maklumat dalam organisasi, kini sistem maklumat merupakan salah satu komponen strategik yang mengintegrasikan pelbagai fungsi dalam organisasi (Tang \& Walters, 2010) bagi menyokong pengurusan dan pentadbiran organisasi. Sistem maklumat amat diperlukan bagi memenuhi keperluan organisasi yang semakin kompleks dan dinamik. Penggunaan sistem maklumat dipengaruhi oleh pelbagai elemen yang dibekalkan oleh sistem dan persekitaran organisasi di mana sistem tersebut digunakan. Antara elemen sistem yang mempengaruhi kejayaan sistem maklumat ialah reka bentuk dan keupayaan sistem, manakala persekitaran organisasi termasuk gaya dan strategi pengurusan, peraturan, polisi, dan komitmen pelbagai pihak yang terlibat dengan pelaksanaan sistem tersebut.

Banyak kajian yang telah dilakukan untuk melihat impak elemen tersebut dengan kejayaan sistem maklumat dan antaranya berkaitan dengan isu penjajaran yang melibatkan sistem maklumat yang digunakan dengan elemen organisasi. Sebagai contoh, penjajaran antara ciriciri pengguna, tugas dan ciri teknologi (Mclaren, Yuan \& Chan, 2011; Sha, Cheng, Pan \& Teoh, 2011; Goodhue \& Thomson, 1995) dan penjajaran antara strategi sistem maklumat dengan elemen organisasi (Tallon \& Pinsonneault, 2011:Kearns \& Sabherwal, 2007)Di samping itu, kajian berkaitan dengan hubungan antara pelbagai aspek penjajaran dengan kejayaan sistem atau pencapaian organisasi juga menarik minat ramai penyelidik dalam bidang sistem maklumat. Antara contoh kajian ialah kajian yang dijalankan oleh Yue-Yang Chen, Shang-Pao Yeh \& Hui-Ling Huang (2012), Raid Moh'd Al-adaileh (2009) dan Alkhalifah \& D’Ambra (2011).

Kajian ini melihat kepada pengaruh strategi sistem maklumat (SSM), strategi pengurusan organisasi (SPO) dan. penjajaran strategik di antara sistem maklumat, strategi pengurusan organisasi (ISS-OMSF) terhadap kejayaan sistem maklumat yang digunakan di dalam organisasi.Sehubungan itu, persoalan kajian dirumuskan seperti berikut:

RQ1. Apakah hubungan di antara strategi sistem maklumat (SSM), strategi pengurusan organisasi (SPO) dan. penjajaran strategik di antara strategi sistem maklumat, strategi pengurusan organisasi (ISS-OMSF)dengan kejayaan sistem maklumat?

RQ2. Adakah ISS-OMSF merupakan mediator dalam hubungan di antara strategi sistem maklumat (SSM) dan strategi pengurusan organisasi (SPO) dengankejayaan sistem maklumat?

RQ3. Adakah strategi sistem maklumat (SSM), strategi pengurusan organisasi (SPO) dan. ISS-OMSF merupakan peramal kepada kejayaan sistem maklumat?

RQ4. Berapa peratuskah varian dalam kejayaan sistem maklumat boleh diramalkan daripada strategi sistem maklumat (SSM), strategi pengurusan organisasi (SPO) dan. ISSOMSF? 
Artikel ini membincangkan secara umum tentang penyelidikan yang dijalankan termasuk penyataan masalah, kerangka konsep, metodologi dan dapatan kajian. Perbincangan diakhiri dengan rumusan dan cadangan kajian akan datang.

\section{PENYATAAN MASALAH}

Kajian literatur mencadangkan, untuk kejayaan sesuatu sistem maklumat, organisi perlu melihat kepada kedua-dua elemen iaitu elemen teknologi dan elemen organisasi. Sebagai contoh, organisasi perlulah (1) menyediakan sistem maklumat yang mudah guna serta memenuhi kehendak dan keperluan pengguna, (2) melengkapkan pengguna dengan pengetahuan dan kemahiran yang mencukupi bagi membolehkan pengguna mengendalikan sistem tersebut dan (3) proses semasa memperkenalkan teknologi dipermudahkan. Oleh itu, untuk memastikan kejayaan pelaksanaan sistem maklumat, organisasi perlu melihat dari aspek tenologi, pengurusan organisasi serta pengintegrasian di antara manusia, teknologi dan pengurusan organisasi (MOE, 1997).

Tinjauan literatur juga menunjukkan kajian yang memfokuskan kepada aspek penjajaran sistem maklumat dengan elemen organisasi telah menarik perhatian kepada pengkaji di Eropah dan Cina. Antara contoh-contoh kajian oleh penyelidik di Taiwan ialah kajian yang dilakukan oleh Chi-Hung Yeh et al. (2012) dan kajian oleh Yue-Yang Chen et al. (2012), manakala kajian oleh Goodhue dan Thomson (1995), Goodhue (1998), dan Tallon \& Pinsonneault (2011) dilakukan oleh penyelidik di Eropah. Hasil tinjauan ke atas kajian yang lepas, penyelidik mendapati kajian seumpama ini kurang dilakukan di Malaysia terutama di organisasi di bawah Kementerian Pendidikan Malaysia (KPM). Hasil tinjauan ke atas kajian yang lepas juga memperlihatkan kajian dilakukan oleh kebanyakkan penyelidik dalam bidang teknologi maklumatseperti kajian oleh Chi-Hung Yeh et al. (2012), Yue-Yang Chen et al. (2012), Goodhue dan Thomson (1995), Goodhue (1998), dan Tallon \& Pinsonneault (2011), dilakukan dalam perbagai sektor termasuk sektor perubatan, pengangkutan, perniagaan, dan amat berkurangan kajian dalam sektor pendidikan. Oleh itu, satu kajian yang melibatkan aspek penjajaran di antara elemen sistem maklumat dengan elemen organisasi serta hubungannya dengan kejayaan sistem maklumat perlu dilakukan di Malaysia khususnya dalam bidang pendidikan. Sehubungan itu, kajian ini dilakukan untuk menentukan pengaruh strategi sistem maklumat (SSM), strategi pengurusan organisasi (SPO) dan. penjajaran strategik di antara sistem maklumat, strategi pengurusan organisasi (ISS-OMSF) terhadap kejayaan sistem maklumat yang digunakan di dalam organisasi. Kajian ini juga membina persamaan regresi dan regresi piawai.

\section{KERANGKA KONSEP}

Pembentukan kerangka konsep kajian adalah berpandukan kepada beberapa model penjajaran seperti IS Success Model oleh DeLone and McLean (2003), A Holistic Perspective of Fit (Fit Model) oleh Yue-Yang Chen, Shang-Pao Yeh, Hui-Ling Huang (2012), dan Strategic Aliment Model olehHenderson dan Venkatraman (1993). Kerangka konsep kajian seperti Rajah 1. 


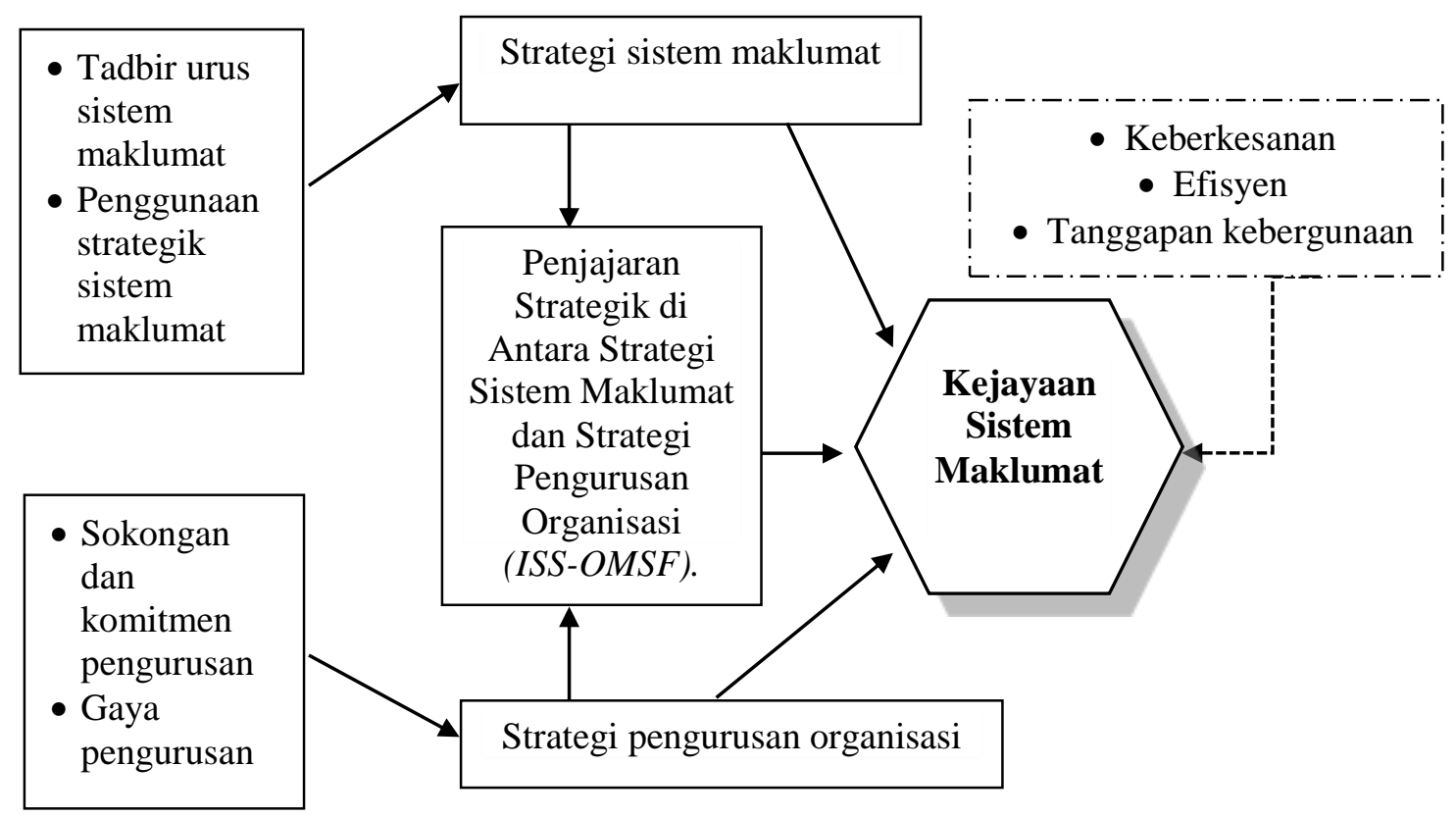

Rajah 1 Kerangka konsep kajian

Terdapat empat komponen utama yang terlibat dalam kajian ia itu strategi sistem maklumat, strategi pengurusan organisasi, penjajaran strategik di antara sistem maklumat, strategi pengurusan organisasi dan kejayaan sistem maklumat. Dalam hal ini, strategi sistem maklumat merupakan satu proses atau tatacara dan langkah-langkah pelaksanaan berkaitan dengan sistem maklumat yang diambil oleh sesebuah organisasi untuk mencapai matlamat dan objektif yang telah ditetapkan. Strategi sistem maklumat juga didefinisikan sebagai gabungan penglibatan semua unit teknologi maklumat yang strategik, proses-proses perancangan, pelaburan dan keputusan untuk menyokong keseluruhan fungsi dan tujuan matlamat organisasi dan objektif (Khadem, 2007). Chen at al. (2010) mencadangkan tiga konsep konstruk strategi sistem maklumat yang utama telah dikenalpasti iaitu penggunaan sistem maklumat untuk menyokong strategi organisasi, strategi sistem maklumat sebagai pelan induk fungsi-fungsi sistem maklumat dan peranan sistem maklumat dalam organisasi. Kajian ini melihat kepada tadbir urus sistem maklumat dan penggunaan strategik sistem maklumat sebagai elemen bagi strategi sistem maklumat.

Strategi pengurusan organisasi pula ditakrifkan sebagai perspektif organisasi yang dikongsi bersama dalam menentukan arah tuju dan matlamat organisasi (Chen, Mocher, Preston dan Teubner, 2010). Secara umumnya strategi pengurusan organisasi merupakan suatu keputusan tentang tatacara dan gaya pengurusan organisasi bagi tujuan untuk menggerakkan organisasi selaras dengan arah, tujuan dan matlamat yang ditentukan. Kajian ini melihat kepada sokongan dan komitmen pihak pengurusan serta gaya pengurusan sebagai elemen bagi strategi pengurusan organisasi.

Berasaskan maksud penjajaran strategik oleh Reich dan Benbasat (1996) dan Henderson dan Venkatraman (1993), kajian ini merujuk ISS-OMSF sebagai pengintegrasian fungsi dan keselarasan strategik di antara strategi sistem maklumat dengan strategi pengurusan organisasi. ISS-OMSF melihat kepada sejauh mana pengintegrasian ini dapat menyokong aktiviti pengurusan dan pentadbiran organisasi. Bagi mencapai penjajaran strategik, kajian yang dilakukan oleh Sha et al. (2011) mendapati sokongan pihak pengurusan atasan 
merupakan elemen penting dalam menentukan penjajaran di antara sistem maklumat dengan pelan organisasi.

Penelitian terhadap hasil kajian lepas menunjukkan terdapat banyak kriteria yang digunakan bagi menilai kejayaan sesuatu sistem maklumat. Antara kriteria yang popular dalam kalangan penyelidik ialah tanggapan kepentingan, tanggapan kebergunaan, penggunaan sistem (Lucas et al, 1990), keberkesanan sistem, dan kecekapan sistem. Manakala, Raid Moh'd Al-adaileh (2009), menggunakan persepsi pengguna melalui kriteria kebergunaan, kemahiran teknikal pengguna. kualiti maklumat, dan sokongan pihak pengurusan untuk menilai sistem maklumat yang digunakan. Dalam kajian ini penilaian terhadap kejayaan pelaksanaan sistem maklumat dalam organisasi dilihat daripada impak yang dimainkan oleh sistem maklumat terhadap organisasi. Antara kriteria penilaian sistem ialah keberkesanan (effectivness), efisyen (efficients), kepuasan kerja (Job satisfaction) dan tanggapan kebergunaan (perceive benefit).

\section{METODOLOGI}

Titik permulaan kajian ini adalah dengan melihat kajian terdahulu berkaitan dengan interaksi di antara elemen sistem maklumat dengan elemen organisasi. Tinjauan literatur berfokus kepada konsep penjajaran di antara sistem maklumat (IS) dengan organisasi, faktor yang mempengaruhi kejayaan sistem maklumat, dan kriteria penilaian sistem maklumat. Instrumen kajian berbentuk soal selidik dan dibina berpandukan kepada instrumen yang telah digunakan oleh penyelidik-penyelidik dalam bidang sistem maklumat seperti Goodhue dan Thomson (1995), DeLone dan McLean (1992), Yue-Yang Chen et al. (2012), dan Al-adaileh (2009). Item-item yang digunakan oleh penyelidik terdahulu ini dipilih dan diolah semula agar bersesuaian dengan kajian di sektor pendidikan terutama di Malaysia. Soal selidik telah melalui beberapa fasa penilaian seperti penilaian oleh tiga orang pakar dalam bidang sistem maklumat, penilaian oleh Penolong Pegawai Pendidikan Daerah dan penilaian oleh pelajar sarjana bagi menentukan item-item adalah releven, jelas dan tidak mengelirukan responden. Kajian rintis dijalankan bagi menentukan kebolehpercayaan instrumen. Sebanyak 50 set borang telah diedarkan kepada guru dan guru data di sekolah di daerah Hulu Perak (sebuah) dan daerah Kinta (sebuah). Nilai kebolehpercayaan pekali Cronbach alpha (Cronbach's coefficient alpha) digunakan bagi mengukur kebolehpercayaan instrumen. Adalah didapati bahawa nilai pekali Cronbach alpha bagi keseluruhan item untuk kajian rintis adalah .97. Oleh itu, instrumen kajian mempunyai kebolehpercayaan yang tinggi kerana nilai skala pekali Cronbach alpha berada di antara .7 dan 1.0 (Hair et. al, 2010, Rahim Utah, 2013).

Responden kajian terdiri daripada guru yang bertugas di 10 buah sekolah menengah yangberada di daerah Hulu Perak, daerah Kuala Kangsar, daerah Muallim, dan daerah Kinta. Pendekatan yang diambil dalam menentukan sekolah-sekolah yang terlibat dalam kajian ialah pensampelan kelompok (cluster sampling) yang melibatkan pensampelan pelbagai peringkat (multistage sampling). Sebanyak 684 set borang soal selidik telah diedarkan kepada semua guru yang bertugas di sekolah yang dikenal pasti dan sebanyak 415 (61.57\%) set borang dikembalikan. Sebelum melakukan analisis terhadap data yang dikumpul, penyelidik terlebih dahulu melakukan empat proses iaitu tapisan data, ujian kebolehpercayaan instrumen, ujian taburan data, dan ujian kepatuhan syarat andaian statistik.Setelah melakukan proses tapisan data, hanya 375 set borang sahaja yang digunakan untuk analisa data. Data di analisis melalui statistik diskriptif, korelasi, dan analisis regresi berganda langkah demi langkah. 


\section{DAPATAN}

Dapatan kajian dibentangkan dalam tiga bahagian iaitu (1) hubungan di antara sistem maklumat (SSM), strategi pengurusan organisasi (SPO) dan. penjajaran strategik di antara sistem maklumat, strategi pengurusan organisasi (ISS-OMSF) dengan kejayaan sistem maklumat, (2) hubungan di antara pemboleh ubah peramal dengan kejayaan sistem maklumat, dan (3) peratusan varian dalam kejayaan sistem maklumat boleh diramalkan daripada pemboleh ubah peramal.

1. Hubungan di antara sistem maklumat (SSM), strategi pengurusan organisasi (SPO) dan penjajaran strategik di antara sistem maklumat, strategi pengurusan organisasi (ISS-OMSF) dengan kejayaan sistem maklumat

Analisis korelasi digunakan bagi melihat hubungan di antara faktor dengan kejayaan sistem maklumat seperti Jadual 1. Dalam Jadual 1 adalah didapati secara statistik terdapat hubungan signifikan di antara strategi sistem maklumat (SSM), strategi pengurusan organisasi (SPO) dan. penjajaran strategik di antara sistem maklumat, strategi pengurusan organisasi (ISSOMSF)dengan kejayaan sistem maklumat (KS), di samping terdapat hubungan di antara SSM dan SPO dengan ISS-OMSF.

Jadual 1: Hubungan di antara pembolehubah kajian

\begin{tabular}{lcccc}
\hline & \multicolumn{2}{c}{ KS } & \multicolumn{2}{c}{ ISS-OMSF } \\
\cline { 2 - 5 } & $r$ & $p$ & $r$ & $p$ \\
\hline SPO & .64 & .00 & .67 & .00 \\
SSM & .61 & .00 & .67 & .00 \\
ISS-OMSF & .77 & .00 & & \\
\hline
\end{tabular}

\section{Hubungan di antara pemboleh ubah peramal dengan kejayaan sistem maklumat}

Bagi menjawab soalan kajian 2 (RQ2) dan soalan kajian 3 (RQ3), analisis regresi berganda digunakan untuk meramal kejayaan sistem maklumatdaripada pembolehubah peramal (faktor) iaitustrategi sistem maklumat dan strategi pengurusan organisasi dan ISS-OMSF. Dalam hal ini, terdapat dua langkah analisis dilakukan ia itu pertama, hubungan terus (tanpa mediasi) di antara strategi sistem maklumat (SSM) dan strategi pengurusan organisasi (SPO) dengan kejayaan sistem maklumat dan kedua, hubungan di antara strategi sistem maklumat (SSM) dan strategi pengurusan organisasi (SPO)dengan kejayaan sistem maklumat (dengan adanya mediasi).

Jadual 2 dan Jadul 3 merupakan dapatan bagi hubungan terus (tanpa mediasi) di antara strategi sistem maklumat (SSM) dan strategi pengurusan organisasi (SPO) dengan kejayaan sistem maklumat. Dapatan menunjukkan bahawa, bagi $N=375$, kedua-dua SSM dan SPO dimasukkan ke dalam model regresi pada $p<.05$. Ini menunjukkan bahawa secara signfikan SPO ( $\beta=0.43$, $p=.00)$ dan SSM $(\beta=0.35, p=.00)$ merupakan peramal kepada kejayaan sistem maklumat, $\mathrm{F}(2,372)=176.14, p=.00$ dan signifikan pada $p<.05$. 
Jadual 2: Jadual statistik F/ANOVA bagi soalan kajian RQ2(R)

ANOVA $^{\mathrm{a}}$

\begin{tabular}{|c|c|c|c|c|}
\hline \multirow{3}{*}{$\begin{array}{c}\text { Model } \\
\text { Regression }\end{array}$} & Sum of Squares & $\mathrm{df}$ & Mean Square & Sig. \\
\hline & & & & \\
\hline & 23.58 & 2 & 11.79 & $176.14 .00^{c}$ \\
\hline Residual & 24.90 & 372 & .07 & \\
\hline Total & 48.47 & 374 & & \\
\hline
\end{tabular}

Dengan merujuk kepada Jadual 3, persamaan regresi adalah seperti berikut:

$$
\begin{aligned}
& \mathrm{y} \text {-hat }(\mathrm{KS})=1.04+0.31(\mathrm{SSM})+0.36(\mathrm{SPO}) \quad \text { Persamaan Regresi } 1 \\
& \mathrm{Z}_{\mathrm{y}-\mathrm{hat}(\mathrm{KS})}=0.35 \mathrm{Z}_{\mathrm{SSM}}+0.43 \mathrm{Z}_{\mathrm{SPO}} \quad \text { Persamaan Regresi Piawai } 1
\end{aligned}
$$

Jadual 3: Output Coefficient bagi soalan RQ2(R)

\begin{tabular}{lll}
\multicolumn{2}{c}{ Coefficients $^{a}$} \\
\hline \multirow{2}{*}{ Model } & \multicolumn{2}{c}{ Unstandardized Coefficients $^{\text {Standardized Coefficients }}$} \\
\cline { 2 - 3 } B & Beta \\
SPO & 1.04 & \\
SSM & 0.36 & 0.43 \\
PSar) & 0.31 & 0.35 \\
\hline
\end{tabular}

a. Pembolehubah bersandar: KS

Jadual 4 dan Jadual 5 digunakan untuk meramal kejayaan sistem maklumatdaripada pembolehubah peramal (faktor) iaitustrategi sistem maklumat dan strategi pengurusan organisasi melalui ISS-OMSF (hubungan di antara SSM dan SPO ke KS dengan mengambil kira kewujudan mediasi). Keputusan analisis data seperti Jadual

Jadual 4 dan Jadual 5 menunjukkan bahawa, bagi $N=375$, didapati ISS-OMSF, SSM dan SPOdimasukkan ke dalam model regresi pada $\mathrm{p}<.05$. Ini bermakna pembolehubah ISS$\operatorname{OMSF}(\beta=0.57, p=.00), \operatorname{SSM}(\beta=0.12, p=.00)$, dan SPO $(\beta=0.19, p=.00)$ merupakan peramal kepada kejayaan sistem maklumat, $\mathrm{F}(3,371)=212.84, p=.00$ dan signifikan pada $p<.05)$. Dalam hal ini, ISS-OMSF tidak bertindak sebagai mediator kerana melepaskan kedua-dua faktor (SSM dan SPO) sebagai peramal signifikan. Sebaliknya, ISS-OMSF menjadi salah satu faktor peramal bagi kejayaan sistem maklumat.Ini jelas dapat dilihat melalui persamaan regresi 2 di mana kedua-dua SSM dan SPO memberi kesan kepada y-hat(KS) walaupun wujud ISSOMSF dalam dalam hubungan tersebut.

\section{Jadual 4: Jadual statistik F/ANOVA bagi soalan kajian RQ2 dan RQ3}




\begin{tabular}{llccccc}
\hline Model & & Sum of Squares & $d f$ & Mean Square & F & Sig. \\
\hline 3 & Regression & 30.66 & 3 & 10.22 & 212.84 & $.00^{\mathrm{d}}$ \\
& Residual & 17.81 & 371 & .05 & & \\
\cline { 2 - 7 } & Total & 48.47 & 374 & & & \\
\hline
\end{tabular}

a. Pembolehubah bersandar: KS

d. Peramal: (Pemalar), ISS-OMSF, SPO, SSM

Dengan merujuk kepada Jadual 5, persamaan regresi adalah seperti berikut:

$\mathrm{y}$-hat $(\mathrm{KS})=0.50+0.10(\mathrm{SSM})+0.16(\mathrm{SPO})+0.59($ ISS-OMSF $) \quad$ Pers. Regresi 2

$\mathrm{Z}_{\mathrm{y} \text {-hat }(\mathrm{KS})}=0.12 \mathrm{Z}_{\mathrm{SSM}}+0.19 \mathrm{Z}_{\mathrm{SPO}}+0.57 \mathrm{Z}_{\mathrm{ISS}-\mathrm{OMSF}}$ Persamaan Regresi Piawai 2

Jadual 5: Output Coefficient bagi soalan kajian RQ2 dan RQ3

Coefficients $^{a}$

\begin{tabular}{|c|c|c|}
\hline & Unstandardized Coefficients & Standardized Coefficients \\
\hline Model & B & Beta \\
\hline 3 (Pemalar) & 0.50 & \\
\hline ISS-OMSF & 0.59 & 0.57 \\
\hline SPO & 0.16 & 0.19 \\
\hline SSM & 0.10 & 0.12 \\
\hline
\end{tabular}

a. Pembolehubah bersandar:KS

\section{Peratusan varian dalam kejayaan sistem maklumat boleh diramalkan daripada pemboleh ubah peramal.}

Jadual 6menunjukkan bahagian varian dalam kejayaan sistem boleh diramalkan daripadaISSOMSF, SPO, dan SSM. Dari Jadual 6didapati secara signifikan (signifikan pada $p<.05$ ), menunjukkan $60 \%(\mathrm{R}=.77)$ bagi varian dalam kejayaan sistem boleh diramalkan daripadaISSOMSF seperti dalam model 1. Model 2 pula menunjukkan $62.6 \%(\mathrm{R}=.791)$ bagi varian dalam kejayaan sistem boleh diramalkan daripada kombinasi linear di antara ISS-OMSF dan SPO iaitu pertambahan sebanyak 2.6\% (62.6\% - 60\%) kepada perubahan varian dalam kejayaan sistem maklumat. Sekiranya, ketiga-tiga peramal iaitu ISS-OMSF, SPO, dan SSM, secara signifikan $63.2 \%(\mathrm{R}=.795)$ bagi varian dalam kejayaan sistem boleh diramalkan daripadaISSOMSF, dan SSM, iaitu pertambahan sebanyak 0.6\% (63.2\% - 62.6\%)kepada bahagian varian dalam kejayaan sistem maklumat, dan dapatan menunjukkan perbezaan pertambahan peratusan yang amat kecil juka dibandingkan dengan kombinasi linear di antara ISS-OMSF dan SPO.

Jadual 6: Analisis Coefficient of determination $\left(\mathbf{R}^{2}\right)$ bagi soalan kajian RQ4

\begin{tabular}{ccccc}
\multicolumn{5}{c}{ Model Summary $^{d}$} \\
\hline Model & $\mathrm{R}$ & $\mathrm{R}^{2}$ & ${\text { Adjusted } \mathrm{R}^{2}}$ & Std. Error of the Estimate \\
\hline 1 & $.77^{\mathrm{a}}$ & .60 & .60 & .23 \\
2 & $.791^{\mathrm{b}}$ & .626 & .62 & .22 \\
3 & $.795^{\mathrm{c}}$ & .632 & .63 & .22 \\
\hline
\end{tabular}

a. Peramal: (Pemalar), ISS-OMSF

b. Peramal: (Pemalar), ISS-OMSF, SPO 
c. Peramal: (Pemalar), ISS-OMSF, SPO, SSM

d. Pembolehubah bersandar: KS

\section{RUMUSAN DAN CADANGAN}

Dapatan kajian menunjukkan terdapat hubungan positif di antara strategi sistem maklumat dan strategi pengurusan organisasi dengan ISS-OMSF dan terdapat korelasi positif di antara sistem maklumat, strategi pengurusan organisasi dan. ISS-OMSF dengan kejayaan sistem maklumat. Di antara ketiga-tiga elemen ini, adalah didapati penjajaran strategik di antara sistem maklumat, strategi pengurusan organisasi (ISS-OMSF)mempunyai hubungan yang kuat dengan kejayaan sistem, diikuti oleh strategi pengurusan organisasi (SPO) dan strategi sistem maklumat (SSM). Ini bermakna kejayaan sistem maklumat lebih banyak dipengaruhi oleh penjajaran strategik di antara sistem maklumat dengan strategi pengurusan organisasi (ISSOMSF)dan merupakan suatu kaedah yang berkesan bagi pembangunan dan penggunaan sistem maklumat bagi menyokong aktiviti organisasi (Issa-Salwe et. al, 2010),jika dibandingkan dengan SSM dan SPO. Oleh itu, organisasi perlulah menitikberatkan isu penjajaran ini bagi memastikan kejayaan sistem maklumat yang lebih tinggi.

Untuk hubungan terus di antara strategi sistem maklumat (SSM) dan strategi pengurusan organisasi (SPO) dengan kejayaan sistem maklumat (tanpa ISS-OMSF), dapatan menunjukkan kedua-dua strategi sistem maklumat dan strategi pengurusan organisasi merupakan peramal kepada kejayaan sistem maklumat. Daripada kedua-dua peramal ini, strategi pengurusan organisasi merupakan peramal yang lebih dominan dalam menentukan kejayaan sistem maklumat iaitu $41 \%$ varian dalam kejayaan sistem maklumat diramalkan oleh strategi pengurusan organisasi. Manakala bahagian varian dalam kejayaan sistem maklumat yang boleh diramalkan daripada SPO bersama SSM hanya 49\%. Selaras dengan kajian lepas, antara SPO yang dicadangkan dalam kajian ini ialah sokongan, galakan, dan komitmen pihak pengurusan kepada setiap aktiviti berkaitan dengan penggunaan sistem maklumat di organisasi (Buchwald, Urbach, \& Ahlemann, 2014; Ferreira, \& Kuniyoshi, 2015; Johnson, 2013; Shahin Dezdar \& Sulaiman Ainin, 2011).

Analisis regresi berganda yang digunakan untuk menentukan peramal kepada kejayaan sistem maklumat juga menunjukkan strategi sistem maklumat, strategi pengurusan organisasi dan ISS-OMSF merupakan peramal kepada kejayaan sistem maklumat. Dapatan juga menunjukkan bahawa penjajaran strategik di antara sistem maklumat dengan strategi pengurusan organisasi (ISS-OMSF) tidak bertindak sebagai mediator kerana melepaskan kedua-dua faktor (SSM dan SPO) sebagai peramal signifikan. Sebaliknya, ISS-OMSF menjadi salah satu faktor peramal penting bagi kejayaan sistem maklumat.

Dalam menentukan peratus varian dalam kejayaan sistem maklumat boleh diramalkan daripada sistem maklumat, strategi pengurusan organisasi dan ISS-OMSF, dapatan menunjukkan 60\% bagi varian dalam kejayaan sistem boleh diramalkan daripada ISS-OMSF, manakala $63.2 \%$ bagi kombinasi ISS-OMSF, sistem maklumat dan strategi pengurusan organisasi. Ini bermakna aspek penjajaran di antara sistem maklumat dan strategi pengurusan organisasi merupakan peramal penting yang mempengaruhi kejayaan sistem maklumat. Kepentingan penjajaran strategik di antara strategi sistem maklumat dengan strategi pengurusan organisasi, bagi meningkatkan keefisyenan sistem maklumat yang digunakan untuk menyokong aktiviti organisasi juga dicadangkan oleh Kaoutar dan Bounabat (2010) dan Yue-Yang Chen et al. (2012). Oleh itu kajian ini mencadangkan tanpa strategi pengurusan yang memberi tumpuan 
kepada aspek penjajaran antara kedua-dua elemen ini akan memberi impak yang negatif terhadap kejayaan sistem maklumat. Dengan itu, hasil kajian ini dapat memberi gambaran serta panduan kepada pihak-pihak yang terlibat dengan pelaksanaan sistem untuk sesebuah organisasi dalam merangka kaedah serta tatacara penggunaan sistem maklumat. Dalam hal ini, tumpuan perlulah kepada aspek penjajaran di antara sistem maklumat dan strategi pengurusan organisasiyang meliputi tadbir urus dan penggunaan strategik sistem maklumat, sokongan dan komitmen pihak pengurusan serta gaya pengurusan.

Selain daripada itu, persamaan regresi yang dibina dalam kajian ini boleh digunakan untuk meramalkan pengaruh atau impak yang dimainkan oleh pembolehubah tidak bersandar ke atas pembolehubah bersandar seperti menentukan bahagian varian dalam kejayaan sistem maklumat yang boleh diramalkan daripada faktor atau peramal tanpa perlu melakukan kajian seumpama ini lagi. Sehubungan itu dicadangkan kajian seterusnya dilakukan dengan mengambilkira persamaan regresi hasil kajian ini,

Kajian ini dijalankan di institusi di bawah KPM sebagai usaha untuk mengisi ketandusan koleksi dapatan dalam bidang sistem maklumat khususnya bagi sektor pendidikan di Malaysia. Oleh kerana kajian yang dijalankan ini hanya melibatkan guru-guru dari sekolah yang dikategorikan sebagai Sekolah Menengah Kebangsaan sahaja, penyelidik mencadangkan kajian seumpama ini yang melibatkan lebih ramai lagi responden, dan diperluaskan kepada semua kategori sekolah seperti sekolah menengah teknik, sekolah menengah agama dan lainlain institusi pendidikan.

\section{RUJUKAN}

Alkhalifah, A. \& D'Ambra, J. (2011). Applying task-technology fit to the adoption of identity management systems. ACIS 2011 Proceedings, Paper 31.

Buchwald, A. Urbach, N., \& Ahlemann, F. (2014). Business value through controlled IT: toward an integrated model of IT governance success and its impact. Journal of Information Technology, 29, 128-147. doi:10.1057/jit.2014.3

Chen, D. Q., Mocker, M., Preston, D. S., \& Teubner, A. (2010). Information systems strategy: reconceptualization, measurement, and implications. MIS Quarterly, 34(2), 233-A8.

Chen, Y., Yeh, S. \& Huang, H. (2012). Does knowledge management "fit" matter to business performance? Journal of Knowledge Management, vo1 6 Issue: 5.

DeLone, W. H., \& McLean, E. R. (1992). Information system success: The quest for the dependent variable, Information Systems Research, v3, n1, pp 60-95.

DeLone, W. H., \& McLean, E. R. (2003). The DeLone and McLean Model of information system success: a ten-year update. Journal of Management Information Systems, spring, v19, n4, pp 9-30.

Ferreira, A. A., \& Kuniyoshi, M. S. (2015). Critical factors in the implementation process of Integrated Management Systems. Journal of Information Systems and Technology Management, 12(1), 145-164. doi:10.4301/S1807-17752015000100008

Goodhue, D. L., \& Thompson, R. L. (1995). Task-technology Fit and individual performance. MIS Quarterly, June, v19, n2, pp 213-237.

Hair, J.E., Anderson, R.E., Tatham, R. L, \&.Black, R.L. (2010). Multivariate data analysis with readings. Englewood Cliffs, N.J: Prentice Hall.

Johnson, M. (2013). Critical success factors for B2B e-markets: a strategic fit perspective. Marketing Intelligence \& Planning, 31(4), 337-366. doi:10.1108/02634501311324843

Kaoutar, E., \& Bounabat, B. (2010). Strategic Alignment Assessment Based on Enterprise Architecture. International Conference on Information Management and Evaluation, 179-187. Diperoleh daripada 
http://search.proquest.com.ezpustaka.upsi.edu.my/science/docview/869737850/1256EEEB9A0 8448APQ/7?accountid=13155

Kearns, G. S., \& Sabherwal, R. (2007). Strategic alignment between business and information technology: a knowledge-based view of behaviors, outcome, and consequences. Journal of Management Information Systems (23:3), pp. 129-162.

Khadem, K. N. (2007). Aligning enterprise and information technology strategy: A study of the correlation between strategic alignment and adaptation of enterprise-wide strategy formulation processes. (Order No. 3255611, Capella University). ProQuest Dissertations and Theses, , 115-115 p. Retrieved from http://search.proquest.com/docview/304722267?accountid=13155. (304722267).

Lucas, H. C., Ginzberg, M. J., \& Schultz, R. L. (1990). Information systems implementation-testing: A Structural Model, Abex Publishing Corporation, USA.

Rahim Utah. (2013). IBM Statistics for windows. Diperolehi daripadahttp://www. Rahimutah.uitm.edu.my/v25/image/ebook-SPSSversi21-2013.pdf.

Raid Moh'd Al-adaileh. (2009). An evaluation of information systems success: a user perspective - the case of Jordan Telecom Group. European Journal of Scientific Research, v37 (2), pp.226-239.

Sha, X., Cheng, Y., Pan, S. L., \& Teoh, S.Y. (2011). The implementation success of healthcare Information systems: A business-IT alignment. Perspective the 19th European Conference on Information Systems, Helsinki, pp 1-14.

Shahin Dezdar, \& Sulaiman Ainin. (2011). The influence of organizational factors on successful ERP implementation, Management Decision, 49(6), 911-926. doi:10.1108/00251741111143603

Tallon, P. P. \& Pinsonneault, A. (2011). Competing perspectives on the link between strategic information technology alignment and organizational agility: insights from a mediation model. MIS Quarterly, v35 (2), pp. 463-486.

Yeh, C., Lee, G. \& Pai, J. (2012). How information system capability affects e-business information technology strategy implementation: An empirical study in Taiwan. Business Process Management Journal, v18 (2) pp. 197 - 218. http://dx.doi.org/10.1108/14637151211225171

Yue-Yang Chen, Shang-Pao Yeh, \& Hui-Ling Huang. (2012). Does knowledge management "fit" matter to business performance? Journal of Knowledge Management, 16 (ㅁ). 671-687. doi $10.1108 / 13673271211262745$ 